\title{
Adaptability study of banana (Musa paradisiacal var. sapiertum) varieties at Jinka, southern Ethiopia
}

\author{
Tekle Yoseph ${ }^{1, *}$, Wondewosen Shiferaw ${ }^{1}$, Zemach Sorsa ${ }^{2}$, Tibebu Simon ${ }^{2}$, Abraham Shumbullo ${ }^{2}$, \\ Woineshet Solomon ${ }^{3}$ \\ ${ }^{1}$ Southern Agricultural Research Institute, Jinka Agricultural Research Center, Department of Crop Science Research Process, Jinka, Ethiopia \\ ${ }^{2}$ Department of Plant Sciences and Horticulture, Wolaita Sodo University, Wolaita Sodo, Ethiopia \\ ${ }^{3}$ Southern Agricultural Research Institute, Hawassa Agricultural Research Center, Department of Crop Science Research Process, Hawassa, \\ Ethiopia
}

\section{Email address: \\ tganta@yahoo.com (T. Yoseph)}

\section{To cite this article:}

Tekle Yoseph, Wondewosen Shiferaw, Zemach Sorsa, Tibebu Simon, Abraham Shumbullo, Woineshet Solomon. Adaptability Study of Banana (Musa Paradisiacal var. Sapiertum) Varieties at Jinka, Southern Ethiopia. American Journal of Agriculture and Forestry.

Vol. 2, No. 6, 2014, pp.250-255. doi: 10.11648/j.ajaf.20140206.13

\begin{abstract}
A field experiment involving eleven improved banana (Musa paradisiacal var. sapiertum) varieties and one local check was carried out at Jinka Agricultural Research Center during the 2006 to 2009 cropping seasons under rain fed conditions to identify the best performing variety to the target areas of South Omo Zone. The banana varieties included in the field experiment were eleven improved (Kampala, Pisang, Lacatan, Poyo, Dwarf Cavendish, Giant Cavendish, Butuzua, Grand Naine, Robusta, Williams-1, Williams-2) and a local check. The experimental design was a randomized complete block design (RCBD) with three replications. Phenological and growth parameters, bunch yield and yield components were studied. The result showed that days to flowering were significantly affected by variety while days to maturity were not significantly influenced by variety. Psedostem height was significantly affected by variety; whereas, variety had brought no significant effect on psedostem circumference. All the yield and yield components studied were significantly affected by variety except finger diameter. Bunch yield advantages of 59.11\%, 55.87\% and 47.55\%, were obtained from the improved banana varieties Dwarf Cavandish, Giant Cavandish and Poyo, respectively over the local check. The highest bunch yields of (45.333 $\left.\mathrm{t} \mathrm{ha}{ }^{-1}\right)$ and (42.000 t ha ${ }^{-1}$ ) were recorded for the varieties Dwarf Cavendish and Giant Cavendish, respectively. Therefore, it can be concluded that use of the improved banana varieties such as Dwarf Cavendish or Giant Cavendish is advisable and could be appropriate for banana production in the test area even though further testing is required to put the recommendation on a strong basis.
\end{abstract}

Keywords: Banana Variety, Bunch Yield, Growth Parameters, Phenological Parameters, Yield Components

\section{Introduction}

Banana (Musa paradisiacal var. sapiertum) is one of the most important tropical fruits and evolved in the humid tropical regions of South East Asia with India as one of its centers of origin. Banana represents the world's second largest fruit crop with an annual production of 129,906,098 metric tons [1]. It ranks as the fourth most important global food commodity after rice, wheat and maize in terms of gross value of production [2]. About 70 million people are estimated to depend on banana fruit for a large proportion of their daily carbohydrate intake [3]. Banana is the major staple food in developing countries. The fact that it produces fruit throughout the year adds to its importance as a food security crop in Africa. It is a primary food and cash crop for over 30 million people in East Africa. Banana is now a major food crop in Africa estimated to meet more than a quarter of the food energy requirements in the continent [4]. It is a staple food and good source of income for a number of African countries especially East and Central Africa [5]. Banana is a source of potassium, magnesium, copper, manganese and vitamin $\mathrm{C}$, but is low in iron and vitamin A [6].

Uganda is Africa's largest producer while Rwanda and Burundi are the second and third largest producers in East Africa, respectively [7]. Banana has been cultivated for several years in Ethiopia as a garden plant. In Ethiopia, the 
major banana producing regions are Southern, Oromia and Amhara regions [8]. During the 2010/2011 production season about $31,885.86$ hectares of land has been covered with banana and the estimated annual production was about 270571.516 tones [9]. The actual yields are less than $40 \mathrm{t} \mathrm{ha}^{-1}$ year $^{-1}[10]$; whereas, the potential yield of banana is greater than $70 \mathrm{t} \mathrm{ha}^{-1}$ year $^{-1}$ [11]. The poor productivity of banana has been attributed to a number of biophysical factors [12].

Banana is the most important crop in Ethiopia, but over the years a number of problems tend to faced against the production of this crop in the country. Out of these, lack of improved varieties is the critical problem to banana. It is the most important cash crop in some parts of Southern Ethiopia, especially Gamo Gofa Zone. But, banana production is also familiar in South Omo Zone of Southern Ethiopia. Though, the crop is important in the target area, a number of factors constrained productivity of the crop in the target areas. This is associated with the lack of improved varieties has been appreciated as one of the primary sources of lower banana production in the target areas. There had no trend of using improved of banana varieties in the existing production system, so that it was the number one problem in the study areas. Hence; there is need to introduce improved banana varieties to the target area is crucial for banana production and productivity. Therefore, this study is aimed at and initiated with the objective of selecting the best performing banana varieties to the target area.

\section{Materials and Methods}

\subsection{Description of the Study Area}

The experiment was conducted at research farm of Jinka Agricultural Research Center located 729 kms South West of the capital Addis Ababa at E $36^{\circ} 33^{\prime}$ '02.7' Longitude and N $05^{\circ} 46^{\prime} 52.0$ " Latitude and at an altitude of 1383 meters above sea level. The long term weather data for the center revealed that the maximum and minimum monthly average temperature of the center is $27.55^{\circ} \mathrm{C}$ and $16.55^{\circ} \mathrm{C}$, respectively; whereas, the maximum and minimum monthly average temperature of the growing periods was $27.576^{\circ} \mathrm{C}$ and $16.622^{\circ} \mathrm{C}$, respectively. The long term rainfall data for the area showed that the mean annual rainfall of the area is $1274.67 \mathrm{~mm}$; while the mean monthly rainfall of the area for the growing seasons was $121.7188 \mathrm{~mm}$. Rainfall pattern of the area over the years have been bi-modal with peaks around September and October and spans from February to November. The experiment was conducted during the 2006 to 2009 cropping seasons under rain fed conditions.

Table 1. The Weather Data for Jinka, During the Years 2006 to 2009.

\begin{tabular}{llll}
\hline Month & MaximumTemp. $\left({ }^{\mathbf{c}} \mathbf{c}\right)$ & Minimum Temp. $\left({ }^{\mathbf{o}} \mathbf{c}\right)$ & Rainfall $(\mathbf{m m})$ \\
\hline January & 31.22 & 15.71 & 56.65 \\
February & 30.71 & 17.22 & 67.05 \\
March & 28.35 & 17.25 & 115.28 \\
April & 26.51 & 17.23 & 190.98 \\
May & 26.43 & 17.61 & 150.85 \\
June & 26.66 & 16.66 & 172.70 \\
July & 26.23 & 16.55 & 59.00 \\
August & 25.92 & 16.76 & 105.23 \\
September & 27.18 & 17.38 & 130.35 \\
October & 26.66 & 17.24 & 188.73 \\
November & 25.71 & 16.17 & 128.63 \\
December & 25.32 & 16.09 & 95.20 \\
\hline
\end{tabular}

\subsection{Treatments and Experimental Design}

The experiment was executed by using eleven improved banana varieties and one local check. The field experiment was laid out in a randomized complete block design (RCBD) with three replications. Four banana plants were used in a single plot basis by using square planting method to make a unit plot area in spacing of $2.5 \mathrm{~m}$ between rows and $2.5 \mathrm{~m}$ between plants within a row making a gross plot area of 25 $\mathrm{m}^{2}$.

\subsection{Data Collection}

\subsubsection{Phenological Parameters and Growth Parameters}

Phenological parameters such as days to flowering and days to maturity were recorded. Days to flowering was recorded by counting the number of days after establishment when $50 \%$ of the plants per plot had the first open flower. Days to maturity were recorded when $90 \%$ of flowers per plot was matured. At mid flowering stages crop growth parameters such as psedostem height and Psedostem Circumference were measured.

\subsubsection{Bunch Yield and Yield Components}

The matured bunch was harvested for determination of bunch yield. Number of hands per bunch, number of fingers per hand, bunch weight, finger weight per hand and finger diameter was measured. All the phenological, growth, yield and yield components were recorded at every harvest of the growing period. All the data recorded throughout the growing periods were averaged over every harvest in the growing seasons for data analysis and computation. The weight of a bunch is determined by the total number of hands per bunch and fingers produced per hand, therefore, the weight of bunch is a function of the total number of hands and fingers obtained from the entire bunch. 


\subsection{Statistical Analysis}

Analysis of variance was performed using the GLM procedure of SAS Statistical Software Version 9.1 [13]. Effects were considered significant in all statistical calculations if the P-values were $\leq 0.05$. Means were separated using Fisher's Least Significant Difference (LSD) test.

\section{Results and Discussion}

The analysis of variance results for mean squares revealed that days to flowering and days to maturity were significantly $(\mathrm{P}<0.01)$ influenced by varieties (Table 2$)$. The analysis of variance result for mean squares also depicted that psedostem height was significantly $(\mathrm{P}<0.001)$ affected by varieties while; psedostem circumference was not significantly affected by varieties (Table 2).

Table 2. Mean Square Values for Crop Phenology and Growth Parameters of Banana at Jinka, in 2006 to 2009.

\begin{tabular}{llllll}
\hline Source & DF & Days to Flowering & Days to Maturity & Psedostem Height (m) & Psedostem Circumference (cm) \\
\hline Replication (R) & 2 & $420.1512 \mathrm{~ns}$ & $2975.076 \mathrm{~ns}$ & $0.3673 \mathrm{~ns}$ & $.1 .98 \mathrm{~ns}$ \\
Variety (VAR.) & 11 & $2141.315^{* *}$ & $15461.48^{* *}$ & $1.0103 * * *$ & $5.98 \mathrm{~ns}$ \\
Error & 22 & 548.15767 & 4303.0304 & 0.1537 & 9.62 \\
\hline
\end{tabular}

*, ** and *** indicate significance at $\mathrm{P}<0.05, \mathrm{P}<0.01$ and $\mathrm{P}<0.001$, respectively and 'ns' indicate non significant

Table 3. Crop Phenology and Growth Parameters of Banana as Affected By Variety at Jinka, in 2006 to 2009.

\begin{tabular}{lllll}
\hline Treatments & Days toFlowering & Days to Maturity & Psedostem Height (m) & Psedostem Circumference (cm) \\
\hline Variety(Var) Kampala & $221.06 \mathrm{ab}$ & $451.25 \mathrm{bc}$ & $1.9533 \mathrm{bc}$ & $44.00 \mathrm{bcd}$ \\
Pisang & $202.22 \mathrm{ab}$ & $380.19 \mathrm{bcd}$ & $1.3233 \mathrm{cde}$ & $40.333 \mathrm{~cd}$ \\
Lacatan & $212.86 \mathrm{ab}$ & $451.48 \mathrm{bc}$ & $1.9567 \mathrm{bc}$ & $41.667 \mathrm{~cd}$ \\
Poyo & $187.89 \mathrm{~b}$ & $353.56 \mathrm{~cd}$ & $2.1433 \mathrm{~b}$ & $45.000 \mathrm{bc}$ \\
Dwarf Cavendish & $227.97 \mathrm{ab}$ & $311.67 \mathrm{~d}$ & $1.0333 \mathrm{e}$ & $44.000 \mathrm{bcd}$ \\
Giant Cavendish & $234.84 \mathrm{a}$ & $483.00 \mathrm{ab}$ & $1.9000 \mathrm{bcd}$ & $50.667 \mathrm{a}$ \\
Butuzua & $187.96 \mathrm{~b}$ & $399.67 \mathrm{bcd}$ & $1.8000 \mathrm{bcd}$ & $41.333 \mathrm{~cd}$ \\
Grand Nain & $206.89 \mathrm{ab}$ & $415.93 \mathrm{bcd}$ & $1.6567 \mathrm{bcde}$ & $49.667 \mathrm{ab}$ \\
Robusta & $225.37 \mathrm{ab}$ & $357.04 \mathrm{bcd}$ & $1.6933 \mathrm{bcde}$ & $37.000 \mathrm{~d}$ \\
Williams-1 & $212.96 \mathrm{ab}$ & $419.78 \mathrm{bcd}$ & $1.1833 \mathrm{de}$ & $40.667 \mathrm{~cd}$ \\
Williams-2 & $134.63 \mathrm{c}$ & $363.81 \mathrm{bcd}$ & $1.1933 \mathrm{de}$ & $41.667 \mathrm{~cd}$ \\
Local Check & $214.81 \mathrm{ab}$ & $580.93 \mathrm{a}$ & $3.2000 \mathrm{a}$ & $37.667 \mathrm{~cd}$ \\
LSD 0.05 & 39.645 & 111.08 & 0.66 & 4.46 \\
CV (\%) & 11.37 & 15.84 & 22.36 & 6.15 \\
\hline
\end{tabular}

Note: Means with the same letters within the columns are not significantly different at $\mathrm{P}<0.05$.

The result of analysis of variance for mean squares depicted that bunch weight was significantly $(\mathrm{P}<0.001)$ affected by varieties, finger weight was significantly affected $(\mathrm{P}<0.01)$ by varieties (Table 4). This finding has confirmed the previous report [14]. According to the result of analysis of variance for mean squares; number of hands per bunch was significantly $(\mathrm{P}<0.05)$ affected by varieties, number of fingers per hand was significantly $(\mathrm{P}<0.001)$ influenced by varieties whereas; varieties had not brought a significant effect on finger diameter (Table 4). The maximum number of hands per bunch of (7.3333) was recorded for the improved banana variety Pisang and the minimum number of hands per bunch of (4.3333) was recorded for the local check (Table 5). The maximum number of fingers per hand of (80.000), (79.000) and (77.333) were recorded for the improved banana varieties Dwarf Cavendish, Giant Cavendish and Poyo, respectively and the minimum number of fingers per hand of (27.000) was noted for the local check (Table 5). The highest finger weights of $(10.000 \mathrm{~kg}$ hand $\left.^{-1}\right),\left(9.667 \mathrm{~kg} \mathrm{hand}^{-1}\right)$ and $\left(9.000 \mathrm{~kg} \mathrm{hand}^{-1}\right)$ were noted from the improved banana varieties Dwarf Cavendish, Robusta and Giant Cavendish, respectively and the least finger weight of $\left(3.167 \mathrm{~kg} \mathrm{hand}^{-1}\right)$ was recorded from the local check (Table 5). The maximum bunch yields of (45.333 $\left.\mathrm{tha}^{-1}\right),(42.000 \mathrm{tha}$ $\left.{ }^{1}\right)$ and (35.333 $\left.\mathrm{tha}^{-1}\right)$ were recorded from the improved banana varieties Dwarf Cavendish, Giant Cavendish and Poyo, respectively and the minimum bunch yield of (18.533 $\left.\mathrm{t} \mathrm{ha}^{-1}\right)$ was noted from the local check (Table 5). The bunch yield advantages of $59.11 \%, 55.87 \%$ and $47.55 \%$ were obtained from the improved banana varieties Dwarf Cavendish, Giant Cavendish and Poyo, respectively over the local check in this study. The bunch yield advantage obtained from the improved banana varieties is related with the increased number yield attributing parameters such as number of fingers per hand in improved banana varieties than the local check.

According to the above findings, the improved banana varieties had resulted in greater bunch yield than the local 
check. This finding has confirmed the previous reports that indicate the potential of improved banana varieties over the local check [14, 15, and 16]. From the above findings it could be suggested that use of the improved banana varieties had brought a proportional yield increment than the local check.

Table 4. Mean Square Values for Yield and Yield Components in Banana at Jinka, in 2006 to 2009.

\begin{tabular}{|c|c|c|c|c|c|c|}
\hline Source & DF & Bunch Yield (t ha') & $\begin{array}{l}\text { Finger Weight } \\
\left(\mathrm{kg} \mathrm{hand}^{-1}\right)\end{array}$ & $\begin{array}{l}\text { Number of Hands } \\
\left(\text { bunch }^{-1}\right)\end{array}$ & $\begin{array}{l}\text { Number of Fingers } \\
\left(\text { hand }^{-1}\right)\end{array}$ & $\begin{array}{l}\text { Finger Diameter } \\
(\mathrm{cm})\end{array}$ \\
\hline Replication (R) & 2 & $29.204 \mathrm{~ns}$ & $3.0044^{\mathrm{ns}}$ & $3.527 \mathrm{~ns}$ & $271.194 \mathrm{~ns}$ & $0.3027^{\mathrm{ns}}$ \\
\hline Variety (Var.) & 11 & $229.792 * * *$ & $13.109 * *$ & $2.656^{*}$ & $647.868 * * *$ & $0.1563 \mathrm{~ns}$ \\
\hline Error a & 22 & 33.907 & 3.387 & 1.1324 & 111.861 & 0.1008 \\
\hline
\end{tabular}

$*$, ** and $* * *$ indicate significance at $\mathrm{P}<0.05, \mathrm{P}<0.01$ and $\mathrm{P}<0.001$, respectively and 'ns' indicate non significant

Table 5. Yield and Yield Components of Banana as Affected By Variety at Jinka, in 2006 to 2009.

\begin{tabular}{|c|c|c|c|c|c|}
\hline Treatments & Bunch Yield (t ha $\left.{ }^{-1}\right)$ & Finger Weight $\left(\mathrm{kg} \mathrm{hand}^{-1}\right)$ & $\begin{array}{l}\text { Number of Hands } \\
\left(\text { bunch }^{-1}\right)\end{array}$ & $\begin{array}{l}\text { Number of Fingers } \\
\left(\text { hand }^{-1}\right)\end{array}$ & Finger Diameter $(\mathrm{cm})$ \\
\hline \multicolumn{6}{|l|}{ Variety (Var.) } \\
\hline Kampala & 24.000defg & $3.667 \mathrm{~cd}$ & $5.3333 \mathrm{abc}$ & $64.333 \mathrm{ab}$ & $3.8067 \mathrm{a}$ \\
\hline Pisang & $34.000 \mathrm{bcd}$ & 7.167ab & $7.3333 \mathrm{a}$ & $60.000 \mathrm{~b}$ & $3.0833 \mathrm{a}$ \\
\hline Lacatan & $33.333 \mathrm{bcde}$ & $6.333 \mathrm{bcd}$ & $6.6667 \mathrm{ab}$ & $53.000 \mathrm{~b}$ & $3.0900 \mathrm{a}$ \\
\hline Poyo & $35.333 \mathrm{abc}$ & $6.667 \mathrm{abc}$ & $4.6667 \mathrm{bc}$ & $77.333 \mathrm{a}$ & $3.5067 \mathrm{a}$ \\
\hline Dwarf Cavendish & $45.333 a$ & $10.000 \mathrm{a}$ & $6.6667 \mathrm{ab}$ & $80.000 \mathrm{a}$ & $3.4967 \mathrm{a}$ \\
\hline Giant Cavendish & $42.000 \mathrm{ab}$ & $9.000 \mathrm{ab}$ & $5.3333 \mathrm{abc}$ & $79.000 \mathrm{a}$ & $3.5467 \mathrm{a}$ \\
\hline Butuzua & $22.667 \mathrm{efg}$ & 7.167ab & $6.6667 \mathrm{ab}$ & $46.000 \mathrm{~b}$ & $3.2700 \mathrm{a}$ \\
\hline Grand Nain & $33.333 \mathrm{bcde}$ & $7.633 a b$ & $6.0000 \mathrm{abc}$ & $58.667 \mathrm{~b}$ & $3.5700 \mathrm{a}$ \\
\hline Robusta & $30.667 \mathrm{cdef}$ & $9.667 \mathrm{ab}$ & $5.6667 \mathrm{abc}$ & $49.667 b$ & $3.4267 \mathrm{a}$ \\
\hline Williams-1 & $21.333 \mathrm{fg}$ & $8.167 \mathrm{ab}$ & $5.0000 \mathrm{bc}$ & $45.333 b$ & $3.0967 \mathrm{a}$ \\
\hline Williams-2 & $20.000 \mathrm{fg}$ & $7.000 \mathrm{abc}$ & $5.0000 \mathrm{bc}$ & $49.000 \mathrm{~b}$ & $3.3100 \mathrm{a}$ \\
\hline Local Check & $18.533 \mathrm{~g}$ & $3.167 d$ & $4.3333 c$ & $27.000 \mathrm{c}$ & $3.2133 \mathrm{a}$ \\
\hline $\mathrm{CV} \%$ & 19.38 & 25.79 & 18.60 & 18.90 & 9.42 \\
\hline
\end{tabular}

Note: Means with the same letters within the columns are not significantly different at $\mathrm{P}<0.05$.

The result of the Pearson correlation coefficient depicted that, among yield and yield components and some growth and phenological traits in this study, number of hands per bunch $(r=0.24807)$, finger weight $(r=0.23027)$, finger diameter $(r=0.09211)$, psedostem height $(r=0.16236)$, psedostem circumference $(\mathrm{r}=0.30515)$, days to flowering $(\mathrm{r}=0.20209)$ and days to maturity $(\mathrm{r}=0.18577)$ were positively correlated with bunch weight (Table 6). Bunch weight was also correlated significantly positively $(\mathrm{r}=$ $0.577 * * *$ ) with the number of fingers per hand (Table 6). This result is in agreement with the previous report [14]. The number of hands per bunch was negatively correlated with finger weight, finger diameter, psedostem height, psedostem circumference and days to maturity; whereas, it was associated positively with the number of fingers per hand and days to flowering (Table 6). The number of fingers per hand was positively correlated with psedostem height and days to flowering; while, it was correlated negatively with psedostem circumference and days to maturity (Table 6). The number of fingers per hand was positively $(r=0.29422)$ associated with finger weight (Table 6). On the other hand, the total number of fingers per hand was correlated negatively with fruit weight [14]. Finger weight was positively correlated with finger diameter, psedostem height, days to flowering and days to maturity but it was associated negatively with psedostem circumference (Table 6). Finger diameter was positively correlated with psedostem height, psedostem circumference, days to flowering and days to maturity (Table 6). Psedostem height was positively correlated with psedostem circumference but it was correlated negatively with days to flowering (Table 6). On the other hand, psedostem height was correlated significantly positively $(\mathrm{r}=$ $0.518^{* *}$ ) with days to maturity (Table 6). Psedostem circumference was positively associated with days to flowering and days to maturity (Table 6). Days to flowering was positively correlated with days to maturity (Table 6). This result has confirmed the previous findings being reported [14].

It is observed from this result that the major variables contributing to the bunch yield were biologically related and the contributions of such correlated and related variables influence positively the performance of the other, hence, the variables that showed negative association will inhibited the performance of the other and this largely depends on their attributes to the performance of the particular traits measured. From this study, it was possible to observe that for example, the variable bunch weight was positively correlated with all the entire traits in this experiment. This study has confirmed that total number of hands per bunch, number of fingers per hand, finger weight and finger diameter are the major 
contributing factors to bunch yield.

Table 6. Pearson Correlation Coefficient for Nine Traits of the Improved Banana Varieties at Jinka, in 2006 to 2009.

\begin{tabular}{lccccccccc}
\hline Traits & BWT & NHD & NFG & FWT & FDM & PSHT & PSCM & DTF & DTM \\
\hline \multirow{2}{*}{ BWT } & 1 & 0.24807 & $0.577^{* * *}$ & 0.23027 & 0.09211 & 0.16236 & 0.30515 & 0.20209 & 0.18577 \\
& & 0.1446 & 0.0002 & 0.1767 & 0.5931 & 0.3441 & 0.0703 & 0.2372 & 0.278 \\
NHD & & 1 & 0.15969 & -0.26726 & -0.03607 & -0.01087 & -0.05164 & 0.12068 & -0.1821 \\
& & & 0.3522 & 0.1151 & 0.8346 & 0.9498 & 0.7649 & 0.4832 & 0.2878 \\
NFG & & & 1 & 0.29422 & 0.25639 & 0.14796 & -0.06632 & 0.02189 & -0.10999 \\
& & & & 0.0815 & 0.1312 & 0.3891 & 0.7007 & 0.8992 & 0.5231 \\
FWT & & & & 1 & 0.008 & 0.07282 & -0.22296 & 0.03026 & 0.20097 \\
& & & & & 0.9631 & 0.673 & 0.1912 & 0.8609 & 0.2399 \\
FDM & & & & & 1 & 0.12902 & 0.04579 & 0.05074 & 0.00836 \\
& & & & & & & 0.4533 & 0.7909 & 0.7688 \\
0.9614 \\
PSHT
\end{tabular}

$\mathrm{DTF}=$ days to flowering, DTM $=$ days to maturity, $\mathrm{PSCM}=$ psedostem circumference, $\mathrm{PSHT}=$ psedostem height, $\mathrm{FDM}=$ finger diameter, $\mathrm{FWT}=$ finger weight, $\mathrm{NFGS}=$ number of fingers per hand, NHD $=$ number of hands per bunch, $\mathrm{BWT}=$ bunch weight

\section{Summary and Conclusion}

Using improved varieties of banana could make an important contribution to increase agricultural production and productivity in areas like Jinka where there is low practice of using improved technologies such as improved crop varieties. To this end, use of improved banana technologies such as improved varieties could be one of the alternatives to improve productivity by small farmers. However, the use of improved banana varieties is not yet studied in the area. Thus, this research work is initiated to investigate the impact of including improved banana varieties on the existing production system is of paramount important.

Study on banana variety was conducted at Jinka under rain fed conditions in 2006 to 2009 . The objective of the study was to determine the best performing banana varieties that will improve banana production and productivity in the target area. The experiment was carried out using the randomized complete block design (RCBD) with three replications at Jinka in 2006 to 2009. During the field implementation, eleven improved banana varieties and one local check were used. According to the results of analysis of variance, all the phenological and growth parameters were significantly affected by varieties except psedostem circumference. Days to flowering and days to maturity are also phenological determinants of yield including psedostem height at flowering which is almost the time for plant to use all the growth traits to produce their food especially during photosynthesis.

All the yield and yield components studied in this experiment such as bunch yield, number of hands per bunch, number of fingers per hand and finger weight were significantly affected by varieties; whereas, variety had not brought a significant effect on finger diameter. The highest bunch yields of $\left(45.333 \mathrm{t} \mathrm{ha}^{-1}\right)$ and $\left(42.000 \mathrm{t} \mathrm{ha}^{-1}\right)$ were recorded for the banana varieties Dwarf Cavendish and Giant Cavendish, respectively. Therefore, it can be concluded that use of the improved banana varieties such as Dwarf Cavendish or Giant Cavendish is advisable and could be appropriate for banana production in the test area even though further testing is required to put the recommendation on a strong basis.

\section{References}

[1] FAOSTAT (2010). Food and Agricultural Organization of the United Nations. pp. 28-30.

[2] INIBAP (1992). International network for the improvement of banana and plantain. Annual Report. 1992. Montpellier. France. p. 48.

[3] Swennen R, Wilson GF (1983). Response of plantain to mulch and fertilizer. Int. Inst. Trop. Agric. Annual Rep. IITA Ibadan, Nigeria p.187.

[4] Robinson, J.C., 1996. Bananas and Plantains. University Press, Cambridge.

[5] Viljoen, A. 2010. Protecting the African banana (Musa spp): Prospects and challenges. Proceedings of the International Conference on Banana and Plantain in Africa, Acta Horticulturae, 879: 305-313.

[6] Wall, M.M. 2006. Ascorbic acid, vitamin A and mineral composition of banana (Musa spp) and papaya (Carica papaya) cultivars grown in Hawaii. Journal of Food Composition and Analysis, 19: 434-445. 
[7] FAO, 2009. FAOSTAT. In the Food and Agriculture Organization of the United Nations website. http://faostat.fao.org/site/567/default.aspx.

[8] MoA (Ministry of Agriculture) 2011. Animal and Plant Health Regulatory Directorate Crop Variety Register Issue No. 14 June, 2011. Addis Ababa

[9] CSA. 2011. Agricultural sample survey 2010/2011 (2003 E.C.). Report on area and production of major crops. Central Statistical Agency of Ethiopia, Addis Ababa, Ethiopia.

[10] Wairegi, L.W.I., van Asten, P.J.A., 2010. Norms for multivariate diagnosis of nutrient imbalance in the East African highland bananas (Musa spp. AAA-EA). J. Plant Nutr. (in press).

[11] Van Asten, P.J.A., Gold, C.S., Wendt, J., De Waele, D., Okech, S.H.O., Ssali, H., Tushemereirwe, W.K., 2005. The contribution of soil quality to yield and its relation with other banana yield loss factors in Uganda. In: Blomme, G., Gold, C.S., Karamura, E. (Eds.), Proceedings of a Workshop Held on Farmer Participatory Testing of IPM Options for Sustainable Banana Production in Eastern Africa, Seeta,
Uganda, December 8-9, 2003, International Plant Genetic Resources Institute, Montpellier, pp. 100-115

[12] Gold, C.S., Karamura, E.B., Kiggundu, A., Bagamba, F., Abera, A.M.K., 1999. Monograph on geographic shifts in highland cooking banana (Musa, group AAA-EA) production in Uganda. Afr. Crop Sci. J. 7, 223-298.

[13] SAS (2007) Statistical Analysis Systems SAS/STAT user's guide Version 9.1 Cary NC: SAS Institute Inc. USA

[14] Shaibu, A.A., E.A. Majil and M.N. Ogburia. 2012. Yield evaluation of plantain and banana landraces and hybrids in humid agro ecological zone of Nigeria E3 Journal of Agricultural Research and Development Vol. 2(3). pp. 074079

[15] Dzomeku BD, Armo-Annor D, Adjei-Gwen K, Nkakwa A, Akyeampong E, Banning IS (2006). Evaluation of four Musa hybrids in Ghana. Trop. Sc., 43:176-179.

[16] Dzomeku BM, Bam RK, Adu-kwarteng E, Darkey SK, Ankomah AA (2007). Agronomic and physico-chemical evaluation of FHIA 21 in Ghana. Int. J. Agric. Res., 2:92-96. 